\title{
GMR
}

\section{Association between interleukin-4 polymorphisms and risk of pre-eclampsia in a population of Chinese pregnant women}

\author{
J. Chen, M. Zhong and Y.H. Yu \\ Department of Obstetrics and Gynecology, Nanfang Hospital, \\ Southern Medical University, Guangzhou, China \\ Corresponding author: M. Zhong \\ E-mail: zhongmeinfh@163.com
}

Genet. Mol. Res. 16 (2): gmr16029218

Received September 8, 2016

Accepted March 8, 2017

Published April 5, 2017

DOI http://dx.doi.org/10.4238/gmr16029218

Copyright $(2017$ The Authors. This is an open-access article distributed under the terms of the Creative Commons Attribution ShareAlike (CC BY-SA) 4.0 License.

\begin{abstract}
Preeclampsia is a common disease unique to pregnant women, and its development involves many genetics 1 factors. IL-4 is an important regulatory factor of the Th2 cellular immune response, and plays an important role in the induction of placental growth. In this study, we investigated the relationship between $I L-4$ C-590T, C+33T and G-1098T polymorphisms and risk of pre-eclampsia in a population of pregnant women. A case-control study of 196 pregnant women with pre-eclampsia and 257 healthy controls was conducted. Genotyping of $I L-4 \mathrm{C}-590 \mathrm{~T}, \mathrm{C}+33 \mathrm{~T}$ and $\mathrm{G}-1098 \mathrm{~T}$ was performed by polymerase chain reaction-restriction fragment length polymorphism. We observed that the TT genotype, compared to the CC genotype, of $I L-4$ C-590T harbored a lower risk of pre-eclampsia; adjusted OR $(95 \% \mathrm{CI})$ was 0.29 (0.11-0.81). The CT+TT genotype, compared to the CC genotype, harbored a lower risk of pre-eclampsia (adjusted OR $=0.50,95 \% \mathrm{CI}$ $=0.30-0.84)$ in the dominant model. In the recessive model, the TT genotype, compared to the $\mathrm{CC}+\mathrm{CT}$ genotype, harbored a lower risk of pre-eclampsia (adjusted $\mathrm{OR}=0.31,95 \% \mathrm{CI}=0.11-0.86$ ). However,
\end{abstract}

Genetics and Molecular Research 16 (2): gmr16029218 
no significant correlation was observed between the $I L-4 \mathrm{C}+33 \mathrm{~T}$ and G-1098T polymorphisms and risk of pre-eclampsia in three genetic models. In conclusion, $I L-4 \mathrm{C}-590 \mathrm{~T}$ polymorphism could be used as a predictive risk factor for pre-eclampsia.

Key words: IL-4 C-590T; IL-4 C+33T; IL-4 G-1098T; Polymorphism; Pre-eclampsia

\section{INTRODUCTION}

Preeclampsia is a common disease unique to pregnant women, and an estimated about $5 \%$ of pregnant women were be affected with pre-eclampsia (Dekker and Sibai, 1998; Sibai et al., 2005; Aggarwal et al., 2010). There have been many studies on the etiology of preeclampsia (Lwaleed et al., 2011); however, the pathogenesis of pre-eclampsia remains unclear. Many factors play important roles in the development of pre-eclampsia, such as preexisting hypertension, diabetes, high body mass index and obesity (Das, 2015; Hod et al., 2015; Mol et al., 2016). Pre-eclampsia in $35 \%$ of pregnant women is reportedly resulted from genetic factors (Hod et al., 2015). Many genetic factors influence the pathogenesis of pre-eclampsia, such as glutathione S-transferase pi 1, glutathione peroxidase 1, matrix metalloproteinase-9, interleukin-8, tumor necrosis factor- $\alpha$, interleukin-1- $\beta$, insulin receptor genes (Gao et al., 2016; Sun et al., 2016a,b; Tavakkol Afshari et al., 2016; Andraweera et al., 2017).

Interleukin-4 (IL-4), IL-6, and IL-10 produced by T-helper 2 (Th2) cells plays an important role in the inhibition of cellular immunity and induction of placental growth (Gratacs et al., 1998; Yoneyama et al., 2002). IL-4 is an important regulatory factor of the Th2 cellular immune response and has a key role in the promotion of humoral immunity and antagonization of Th1 activity of cytokines (Paul, 2015; Redpath et al., 2015). IL-4 is located on chromosome q531-33. Three common polymorphisms of $I L-4$ were observed, including C-590T, C+33T and G-1098T. Although several recent studies have indicated that many polymorphisms of $I L$ $1 \beta, I L-1 R L 1, I L-8, I L-10, I L-12$ and $I L-33$ are involved in the pathogenesis of pre-eclampsia (Liu et al., 2015; Ren et al., 2016; Sun et al., 2016b; Tavakkol Afshari et al., 2016; Wang et al., 2016). However, only two studies have reported the association of $I L-4$ polymorphism with the development of pre-eclampsia so far (Fraser et al., 2008; Kang et al., 2014). To our knowledge, no study has shown on the correlation of $I L-4 \mathrm{C}+33 \mathrm{~T}$ and G-1098T polymorphisms with the development of pre-eclampsia in the Chinese population. In this study, we investigated the relationship between $I L-4 \mathrm{C}-590 \mathrm{~T}, \mathrm{C}+33 \mathrm{~T}$ and G-1098T polymorphisms and risk of preeclampsia in a population of pregnant women in West China.

\section{MATERIAL AND METHODS}

\section{Subjects}

A case-control study of 196 pregnant women with pre-eclampsia and 257 controls was conducted between January 2013 and December 2015. The patients were recruited from the Department of Obstetrics and Gynecology of Nanfang Hospital of Southern Medical University. Pre-eclampsia was confirmed in the patients through clinical findings. Diagnosis was according to the elevated blood pressure and presence of proteinuria after 20 weeks of

Genetics and Molecular Research 16 (2): gmr16029218 
gestation (ACOG Committee on Practice Bulletins-Obstetrics, 2002). The exclusive criteria for patients included patients with both pre-eclampsia and diabetes, chronic hypertension, multiple pregnancies, or cardiovascular diseases. The mean age of patients was $28.23 \pm 4.93$ years, and the gestational weeks when enrolled were $27.36 \pm 3.93$ weeks.

Healthy controls were recruited from pregnant women who came for childbirth and maternal health care in the Nanfang Hospital of Southern Medical University. The inclusive criteria for the control group included women at more than 20 weeks' gestation with a single pregnancy and without pre-eclampsia, diabetes, chronic hypertension, or cardiovascular diseases. The mean age of this group was $27.42 \pm 4.22$ years, and the gestational weeks when enrolled were $26.80 \pm 4.40$ weeks.

Details of potential risk factors for pre-eclampsia were collected from medical records, including primiparity, tobacco smoking and alcohol consumption status prior to pregnancy, body mass index, family history of pre-eclampsia, systolic blood pressure (SBP), diastolic blood pressure (DBP), 24-h urinary protein content uric acid, and newborn birth weight. Informed consent was obtained from all investigated pregnant women prior to study enrollment. Approval for the study was received from the ethical committee of Nanfang Hospital, Southern Medical University.

\section{Genotyping of $I L-4$ C-590T, C+33T and G-1098T polymorphisms}

Peripheral blood sample (5 $\mathrm{mL}$ from each study participant) was obtained and saved in ethylenediaminetetraacetic acid-containing tubes. Genomic DNA of samples was extracted using a DNA extraction kit (TaKaRa Bio Inc., Dalian, China) according to the manufacturer's instructions. IL-4 C-590T, C+33T and G-1098T genotyping was performed by the polymerase chain reaction (PCR)-restriction fragment length polymorphism method. Primers were supplied by Applied Biosystems (Foster City, CA, USA). The PCR regimen for IL-4 C-590T was as follows: initial denaturation at $94^{\circ} \mathrm{C}$ for $5 \mathrm{~min}$; then 38 cycles of $94^{\circ} \mathrm{C}$ for $30 \mathrm{~s}, 57^{\circ} \mathrm{C}$ for $40 \mathrm{~s}$, and $72^{\circ} \mathrm{C}$ for $60 \mathrm{~s}$; and a final extension at $72^{\circ} \mathrm{C}$ for $7 \mathrm{~min}$. The PCR regimen for $I L-4$ $\mathrm{C}+33 \mathrm{~T}$ was as follows: initial denaturation at $94^{\circ} \mathrm{C}$ for $5 \mathrm{~min}$; then 35 cycles of $94^{\circ} \mathrm{C}$ for $30 \mathrm{~s}$, $54^{\circ} \mathrm{C}$ for $30 \mathrm{~s}$, and $72^{\circ} \mathrm{C}$ for $40 \mathrm{~s}$; and a final extension of $72^{\circ} \mathrm{C}$ for $7 \mathrm{~min}$. The PCR regimen for G-1098T was as follows: initial denaturation at $94^{\circ} \mathrm{C}$ for $5 \mathrm{~min}$; then 35 cycles of $94^{\circ} \mathrm{C}$ for 30 $\mathrm{s}, 60.7^{\circ} \mathrm{C}$ for $45 \mathrm{~s}$, and $72^{\circ} \mathrm{C}$ for $45 \mathrm{~s}$; and a final extension of $72^{\circ} \mathrm{C}$ for $7 \mathrm{~min}$. The amplification reaction was performed in $25-\mu \mathrm{L}$ PCR reaction mixture, and each $25-\mu \mathrm{L}$ PCR included 18.3 $\mu \mathrm{L} \mathrm{H}_{2} \mathrm{O}, 2.5 \mu \mathrm{L} 10 \mathrm{X}$ PCR buffer, $2 \mu \mathrm{L}$ deoxynucleotides, $0.5 \mu \mathrm{L}$ forward primer, $0.5 \mu \mathrm{L}$ reverse primer, $0.2 \mu \mathrm{L} \mathrm{rTaq}$ DNA polymerase, and DNA template. Successful amplification of samples was verified by electrophoresis on a $2 \%$ agarose gel. Finally, the digested product was electrophoresed on a $4 \%$ agarose gel. The electropherograms of PCR products of $I L-4 \mathrm{C}-590 \mathrm{~T}$, $\mathrm{C}+33 \mathrm{~T}$ and G-1098T are shown in Figures 1-3.

\section{Statistical analysis}

The collected demographic and clinical characteristics are reported as their frequencies and percentages or means \pm standard deviation in the patient and control groups. Comparison of these data between groups was conducted using the Chi-square $\left(\chi^{2}\right)$ test or student $t$-test. $I L-4$ C-590T, C+33T and G-1098T genotype frequency deviations from the Hardy-Weinberg equilibrium were estimated by the Chi-square test. The correlation between of IL-4 C-590T,

Genetics and Molecular Research 16 (2): gmr16029218 
$\mathrm{C}+33 \mathrm{~T}$ and $\mathrm{G}-1098 \mathrm{~T}$ polymorphisms and the risk of pre-eclampsia was determined by multiple logistic regression analysis; results were expressed in OR and 95\%CI. Three genetic models were performed in analysis, namely dominant, co-dominant, and recessive models. IBM SPSS Statistics for Windows, Version 20.0. (IBM Corp., Armonk, NY, USA) was used for statistical analysis.

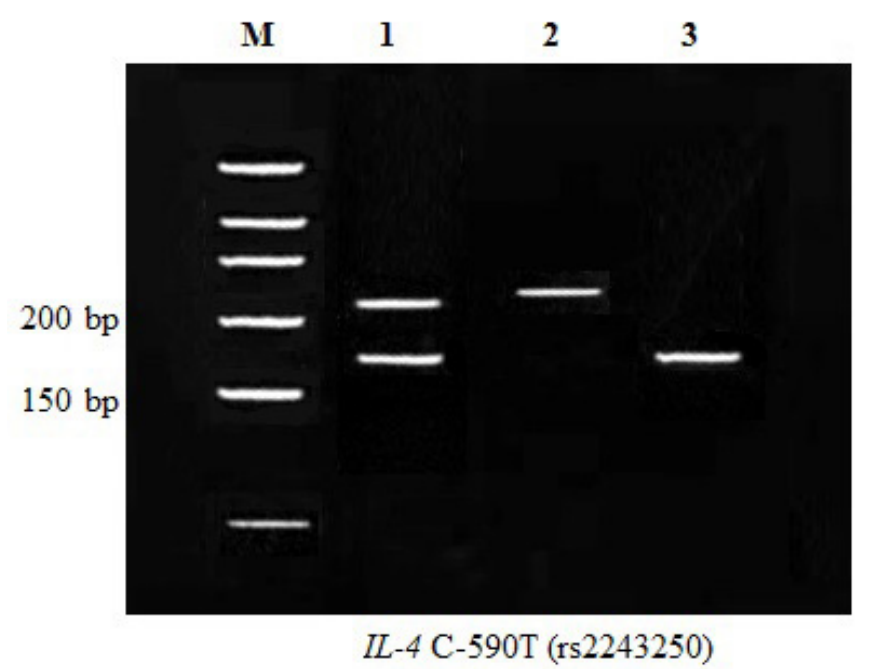

Figure 1. Electropherogram of the PCR products of $I L-4$ C-590T. Lane $M=$ marker (DNA ladder); lane $1=\mathrm{TC}$ genotype; lane 2 = TT genotype; lane $3=\mathrm{CC}$ genotype

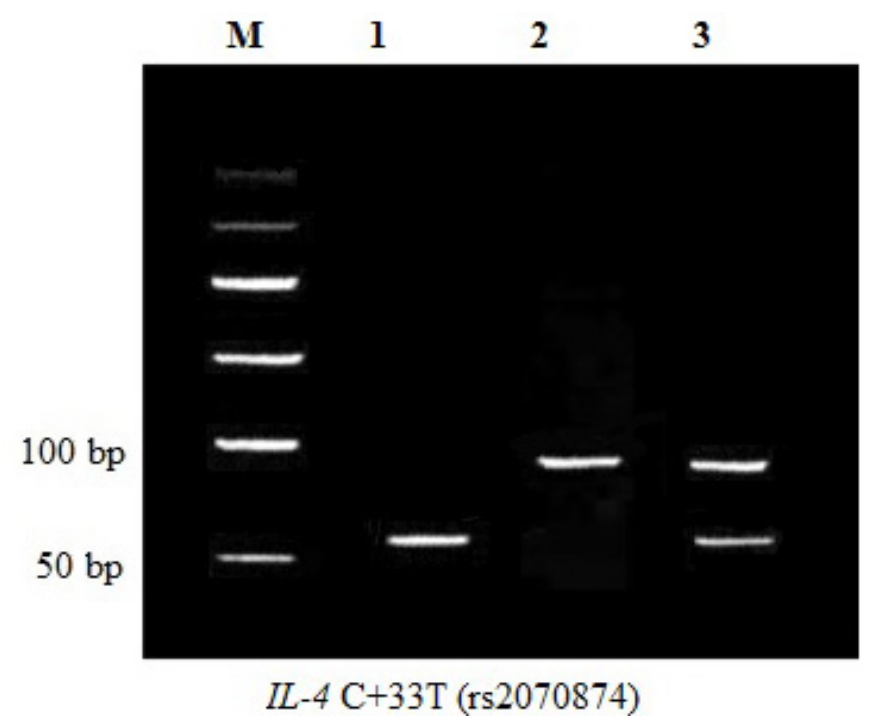

Figure 2. Electropherogram of the PCR products of $I L-4 \mathrm{C}+33 \mathrm{~T}$. Lane $M=$ marker (DNA ladder); lane $1=\mathrm{CC}$ genotype; lanes 2 and $3=\mathrm{TT}$ genotype; lane $4=\mathrm{TC}$ genotype.

Genetics and Molecular Research 16 (2): gmr16029218 


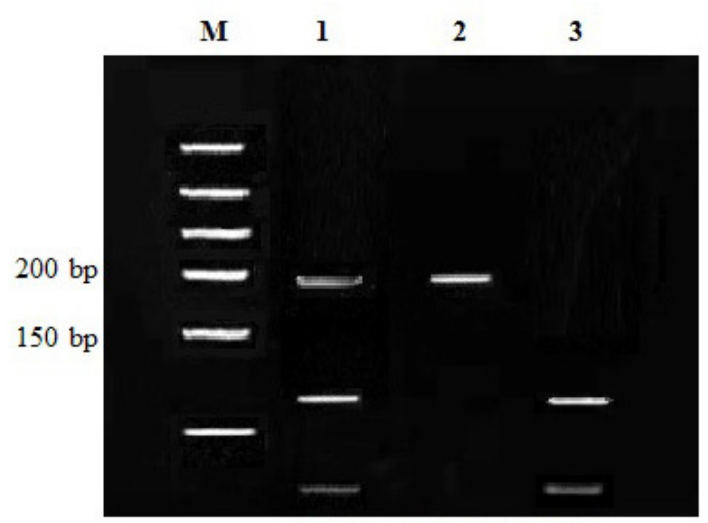

IL-4 G-168A (rs2070874)

Figure 3. Electropherogram of the PCR products of $I L-4$ G-1098T. Lane $M=$ markers (DNA ladder); lane $1=\mathrm{GT}$ genotype; lane 2 = TT genotype; lane $3=\mathrm{GG}$ genotype.

\section{RESULTS}

No significant differences were observed between the pregnant women with pre-eclampsia and controls based on age, gestational weeks, the smoking and drinking status prior to pregnancy, and the family history of pre-eclampsia. However, there were significant differences between patients and controls in terms of body mass index $\left(\chi^{2}=17.16, \mathrm{P}<0.001\right)$, SBP $(\mathrm{t}=53.05, \mathrm{P}<$ $0.001)$, DBP $(\mathrm{t}=5.41, \mathrm{P}=0.02)$, and serum uric acid $(\mathrm{t}=16.65, \mathrm{P}<0.001)$. The 24-h urinary protein content of pregnant women with pre-eclampsia was $2453.06 \pm 487.16 \mathrm{mg}$ (Table 1).

Table 1. Demographic and clinical characteristics of patients with pre-eclampsia and controls.

\begin{tabular}{|c|c|c|c|c|c|c|}
\hline Variables & $\begin{array}{c}\text { Controls } \\
(\mathrm{N}=257)\end{array}$ & $\%$ & $\begin{array}{c}\text { Patients } \\
(\mathrm{N}=196)\end{array}$ & $\%$ & $\chi^{2}$ or $t$ value & $\mathrm{P}$ value \\
\hline Age (years) & $27.42 \pm 4.22$ & & $28.23 \pm 4.93$ & & -1.89 & 0.08 \\
\hline Gestational weeks when enrolled & $26.80 \pm 4.40$ & & $27.36 \pm 3.93$ & & 1.04 & 0.31 \\
\hline \multicolumn{7}{|l|}{ Primiparity } \\
\hline No & 126 & 49.03 & 94 & 47.96 & & \\
\hline Yes & 131 & 50.97 & 102 & 52.04 & 0.51 & 0.82 \\
\hline \multicolumn{7}{|l|}{ Tobacco smoking prior to pregnancy } \\
\hline No & 241 & 93.77 & 179 & 91.33 & & \\
\hline Yes & 16 & 6.23 & 17 & 8.67 & 0.99 & 0.32 \\
\hline \multicolumn{7}{|l|}{ Alcohol drinking prior to pregnancy } \\
\hline No & 215 & 83.66 & 166 & 84.69 & & \\
\hline Yes & 42 & 16.34 & 30 & 15.31 & 0.09 & 0.77 \\
\hline \multicolumn{7}{|l|}{ BMI $\left(\mathrm{kg} / \mathrm{m}^{2}\right)$} \\
\hline$<24$ & 163 & 63.42 & 86 & 43.88 & & \\
\hline$\geq 24$ & 94 & 36.58 & 110 & 56.12 & 17.16 & $<0.001$ \\
\hline \multicolumn{7}{|l|}{ Family history of pre-eclampsia } \\
\hline No & 181 & 70.43 & 126 & 64.29 & & \\
\hline Yes & 76 & 29.57 & 70 & 35.71 & 1.92 & 0.17 \\
\hline SBP $(\mathrm{mmHg})$ & $113.89 \pm 11.79$ & & $141.36 \pm 19.93$ & & 53.05 & $<0.001$ \\
\hline DBP (mmHg) & $76.63 \pm 13.16$ & & $95.06 \pm 15.75$ & & 5.41 & 0.02 \\
\hline 24-h urinary protein content $(\mathrm{mg})$ & \multicolumn{2}{|c|}{$2453.06 \pm 487.16$} & - & & & \\
\hline Serum uric acid $(\mu \mathrm{mol} / \mathrm{L})$ & \multicolumn{2}{|c|}{$333.93 \pm 43.90$} & \multicolumn{2}{|c|}{$406.74 \pm 51.94$} & 8.09 & 0.005 \\
\hline
\end{tabular}

$\mathrm{BMI}=$ body mass index; $\mathrm{SBP}=$ systolic blood pressure; $\mathrm{DBP}=$ diastolic blood pressure.

Genetics and Molecular Research 16 (2): gmr16029218 
The genotype frequencies of $I L-4 \mathrm{C}-590 \mathrm{~T}, \mathrm{C}+33 \mathrm{~T}$ and G-1098T are shown in Table 2. We observed that the TT, TC, and CC genotype frequencies of $I L-4$ C-590T showed significantly different between patients with pre-eclampsia and controls $\left(\chi^{2}=8.04, \mathrm{P}=0.02\right)$. The $I L-4$ $\mathrm{C}+33 \mathrm{~T}\left(\chi^{2}=1.64, \mathrm{P}=0.44\right)$ and $\mathrm{G}-1098 \mathrm{~T}\left(\chi^{2}=0.59, \mathrm{P}=0.74\right)$ genotype distributions were not statistically significant between the two groups. However, the $I L-4$ C-590T genotype frequencies in the controls were not in line with the $\operatorname{HWE}\left(\chi^{2}=12.39, \mathrm{P}=0.004\right)$.

Table 2. Genotype distributions of $I L-4$ C-590T, C+33T and G-1098T in patients with pre-eclampsia and controls.

\begin{tabular}{|c|c|c|c|c|c|c|c|c|c|}
\hline$I L-4$ & & Controls $(\mathrm{N}=257)$ & $\%$ & Patients $(\mathrm{N}=196)$ & $\%$ & $\chi^{2}$ value & $\mathrm{P}$ & $\chi^{2}$ for HWE in controls & $\mathrm{P}$ \\
\hline \multirow[t]{3}{*}{$\mathrm{C}-590 \mathrm{~T}$} & TT & 199 & 77.43 & 169 & 86.22 & & & & \\
\hline & $\mathrm{TC}$ & 37 & 14.40 & 22 & 11.22 & & & & \\
\hline & $\mathrm{CC}$ & 21 & 8.17 & 5 & 2.55 & 8.04 & 0.02 & 12.39 & 0.004 \\
\hline \multirow[t]{3}{*}{$\mathrm{C}+33 \mathrm{~T}$} & TT & 180 & 70.04 & 142 & 72.45 & & & & \\
\hline & TC & 61 & 23.74 & 47 & 23.98 & & & & \\
\hline & $\mathrm{CC}$ & 16 & 6.23 & 7 & 3.57 & 1.64 & 0.44 & 1.50 & 0.22 \\
\hline \multirow[t]{3}{*}{ G-1098T } & GG & 109 & 42.41 & 78 & 39.80 & & & & \\
\hline & GT & 110 & 42.80 & 91 & 46.43 & & & & \\
\hline & TT & 38 & 14.79 & 27 & 13.78 & 0.59 & 0.74 & 0.003 & 0.96 \\
\hline
\end{tabular}

By binary logistic regression models, we observed that the TT genotype of $I L-4 \mathrm{C}-590 \mathrm{~T}$, compared to the $\mathrm{CC}$ genotype, was significantly related to a reduced risk of pre-eclampsia; crude and adjusted ORs $(95 \% \mathrm{CI})$ were $0.28(0.10-0.75)$ and $0.29(0.11-0.81)$ (Table 3). In

Table 3. Association of $I L-4$ C-590T, C+33T and G-1098T polymorphisms with the risk of pre-eclampsia.

\begin{tabular}{|c|c|c|c|c|c|c|c|c|}
\hline$I L-4$ & $\begin{array}{c}\text { Controls } \\
(\mathrm{N}=257)\end{array}$ & $\%$ & $\begin{array}{c}\text { Patients } \\
(\mathrm{N}=196)\end{array}$ & $\%$ & Crude OR & $P$ & OR $(95 \% \mathrm{CI})^{1}$ & $\mathrm{P}$ \\
\hline \multicolumn{9}{|l|}{ C-590T } \\
\hline \multicolumn{9}{|c|}{ Co-dominant } \\
\hline $\mathrm{CC}$ & 199 & 77.43 & 169 & 86.22 & 1.0 (Ref.) & - & 1.0 (Ref.) & - \\
\hline $\mathrm{CT}$ & 37 & 14.40 & 22 & 11.22 & $0.69(0.39-1.22)$ & 0.20 & $0.61(0.34-1.10)$ & 0.10 \\
\hline TT & 21 & 8.17 & 5 & 2.55 & $0.28(0.10-0.75)$ & 0.01 & $0.29(0.11-0.81)$ & 0.02 \\
\hline \multicolumn{9}{|c|}{ Dominant } \\
\hline $\mathrm{CC}$ & 199 & 77.43 & 169 & 86.22 & 1.0 (Ref.) & - & 1.0 (Ref.) & - \\
\hline $\mathrm{CT}+\mathrm{TT}$ & 58 & 22.57 & 27 & 13.78 & $0.54(0.33-0.89)$ & 0.01 & $0.50(0.30-0.84)$ & 0.01 \\
\hline \multicolumn{9}{|c|}{ Recessive } \\
\hline $\mathrm{CC}+\mathrm{CT}$ & 236 & 91.83 & 191 & 97.45 & 1.0 (Ref.) & - & 1.0 (Ref.) & - \\
\hline TT & 21 & 8.17 & 5 & 2.55 & $0.29(0.11-0.79)$ & 0.02 & $0.31(0.11-0.86)$ & 0.03 \\
\hline \multicolumn{9}{|l|}{$\mathrm{C}+33 \mathrm{~T}$} \\
\hline \multicolumn{9}{|c|}{ Co-dominant } \\
\hline $\mathrm{CC}$ & 180 & 70.04 & 142 & 72.45 & 1.0 (Ref.) & - & 1.0 (Ref.) & - \\
\hline $\mathrm{CT}$ & 61 & 23.74 & 47 & 23.98 & $0.90(0.58-1.41)$ & 0.65 & $0.89(0.56-1.40)$ & 0.60 \\
\hline TT & 16 & 6.23 & 7 & 3.57 & $0.54(0.21-1.36)$ & 0.19 & $0.57(0.22-1.48)$ & 0.25 \\
\hline \multicolumn{9}{|c|}{ Dominant } \\
\hline $\mathrm{CC}$ & 180 & 70.04 & 142 & 72.45 & 1.0 (Ref.) & - & 1.0 (Ref.) & - \\
\hline $\mathrm{CT}+\mathrm{TT}$ & 77 & 29.96 & 54 & 27.55 & $0.86(0.56-1.30)$ & 0.46 & $0.84(0.55-1.28)$ & 0.42 \\
\hline \multicolumn{9}{|c|}{ Recessive } \\
\hline $\mathrm{CC}+\mathrm{CT}$ & 241 & 93.77 & 189 & 96.43 & 1.0 (Ref.) & - & 1.0 (Ref.) & - \\
\hline TT & 16 & 6.23 & 7 & 3.57 & $0.54(0.22-1.36)$ & 0.19 & $0.59(0.23-1.51)$ & 0.27 \\
\hline \multicolumn{9}{|l|}{ G-1098T } \\
\hline \multicolumn{9}{|c|}{ Co-dominant } \\
\hline GG & 109 & 42.41 & 78 & 39.80 & 1.0 (Ref.) & - & 1.0 (Ref.) & - \\
\hline GT & 110 & 42.80 & 91 & 46.43 & $1.12(0.74-1.68)$ & 0.59 & $1.14(0.75-1.73)$ & 0.55 \\
\hline TT & 38 & 14.79 & 27 & 13.78 & $1.03(0.57-1.85)$ & 0.92 & $1.12(0.61-2.05)$ & 0.71 \\
\hline \multicolumn{9}{|c|}{ Dominant } \\
\hline GG & 109 & 42.41 & 78 & 39.80 & 1.0 (Ref.) & 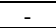 & 1.0 (Ref.) & - \\
\hline $\mathrm{GT}+\mathrm{TT}$ & 148 & 57.59 & 118 & 60.20 & $1.13(0.77-1.66)$ & 0.52 & $1.16(0.78-1.72)$ & 0.56 \\
\hline \multicolumn{9}{|c|}{ Recessive } \\
\hline $\mathrm{GG}+\mathrm{GT}$ & 219 & 85.21 & 169 & 86.22 & 1.0 (Ref.) & - & 1.0 (Ref.) & - \\
\hline TT & 38 & 14.79 & 27 & 13.78 & $0.93(0.54-1.59)$ & 0.79 & $0.98(0.57-1.70)$ & 0.95 \\
\hline
\end{tabular}

${ }^{1}$ Adjusted for age, BMI, SBP, DBP and uric acid.

Genetics and Molecular Research 16 (2): gmr16029218 
the dominant model, we observed that the $\mathrm{CT}+\mathrm{TT}$ genotype, compared to the $\mathrm{CC}$ genotype, showed a lower risk of pre-eclampsia (crude $\mathrm{OR}=0.54,95 \% \mathrm{CI}=0.33-0.89$; adjusted $\mathrm{OR}=$ $0.50,95 \% \mathrm{CI}=0.30-0.84)$. In the recessive model, we found that the TT genotype harbored a 0.31 -fold risk of pre-eclampsia than that by the $\mathrm{CC}+\mathrm{CT}$ genotype (adjusted $\mathrm{OR}=0.31$, $95 \% \mathrm{CI}=0.11-0.86$ ). However, no significant correlation was observed between the $I L-4$ $\mathrm{C}+33 \mathrm{~T}$ and $\mathrm{G}-1098 \mathrm{~T}$ polymorphisms and risk of pre-eclampsia in the co-dominant, dominant and recessive genetic models.

\section{DISCUSSION}

IL-4 C-590T, C+33T and G-1098T polymorphisms, encoding inflammatory factors, may affect an individual's levels of cytokine produced and reaction intensities and are, therefore, correlated with the development of many types of diseases. In the current study, we found that the $I L-4$ C-590T polymorphism harbored a decreased risk of pre-eclampsia in the Chinese population.

Th2 cells produce many types of cytokines, such as IL-4, that are capable of inhibiting cellular immunity and promoting placental growth (Gratacs et al., 1998; Yoneyama et al., 2002). A previous study conducted a study in Iranian patients with pre-eclampsia, and reported that dysregulation of cytokine expression occurred in preeclampsia with a raised levels of IL-4 and other cytokines (Mansouri et al., 2007). Another study observed that the cytokine balance in the Th1/Th2 was broken in pregnant women with pre-eclampsia, encouraging the development of an excessive inflammatory reaction (Vargas-Rojas et al., 2016). Gharesi-Fard et al. (2016) reported that the Th1/Th2/Th17/Treg balance within placenta played an important role in the fate of a normal pregnancy. Therefore, the altered expression of IL- 4 is involved in risk of pre-eclampsia.

Two studies have reported the relationship between $I L-4$ polymorphism and the pathogenesis of pre-eclampsia (Fraser et al., 2008; Kang et al., 2014). Kang et al. (2014) carried out a study on 78 pregnant women with pre-eclampsia and 125 healthy controls in Taiwan and reported the $I L-4$ C-590T polymorphism did not affect the development of preeclampsia. Fraser et al. (2008) have conducted a study on 117 women with pre-eclampsia and 146 normal control subjects in English, which indicated that pregnant women harboring the TT genotype of $I L-4 \mathrm{C}-590 \mathrm{~T}$ was associated with an increased risk of developing pre-eclampsia compared to those carrying the $\mathrm{CC}$ genotype. However, to our knowledge, we firstly reported the association between $I L-4 \mathrm{C}+33 \mathrm{~T}$ and G-1098Tpolymorphisms and risk of pre-eclampsia. The contribution of $I L-4 \mathrm{C}+33 \mathrm{~T}$ and G-1098T polymorphisms to the pathogenesis of many types of inflammation-related diseases, such as asthma, cerebral palsy, wheezing, allergic rhinitis, and chronic hepatitis $\mathrm{C}$ diseases, has been well established by previous studies (Smith et al., 2008; Djukic et al., 2009; Yang, 2013; Zhenzhen et al., 2013). The present study is the first to consider the role of the $I L-4 \mathrm{C}+33 \mathrm{~T}$ and G-1098T polymorphisms in the development of pre-eclampsia and report no significant relationship between the polymorphism and risk of pre-eclampsia.

The present study has two important limitations. First, since all the study participants were recruited from only one hospital, a sample selection bias exists in this study. Second, only 196 pregnant women with pre-eclampsia and 257 controls were recruited in this study, and the results could be undervalued due to the limitation of sample size. Therefore, further large sample size studies should be taken into consideration in future analyses.

Genetics and Molecular Research 16 (2): gmr16029218 
In conclusion, our study suggests that the $I L-4 \mathrm{C}-590 \mathrm{~T}$ polymorphism is independently associated with the risk of pre-eclampsia in all genetic models and could be considered as a risk factor for the disease. Further investigation of larger samples sizes and other ethnicities are needed to validate our findings.

\section{Conflicts of interest}

The authors declare no conflict of interest.

\section{ACKNOWLEDGMENTS}

We are grateful for the special fund for collaborative innovation and platform construction (\#2015B050501006) granted to us.

\section{REFERENCES}

ACOG Committee on Practice Bulletins--Obstetrics (2002). ACOG practice bulletin. Diagnosis and management of preeclampsia and eclampsia. Number 33, January 2002. Obstet. Gynecol. 99: 159-167.

Aggarwal PK, Jain V and Jha V (2010). Endothelial nitric oxide synthase, angiotensin-converting enzyme and angiotensinogen gene polymorphisms in hypertensive disorders of pregnancy. Hypertens. Res. 33: 473-477. http:// dx.doi.org/10.1038/hr.2010.23

Andraweera PH, Gatford KL, Dekker GA, Leemaqz S, et al. (2017). The INSR rs2059806 single nucleotide polymorphism, a genetic risk factor for vascular and metabolic disease, associates with pre-eclampsia. Reprod. Biomed. Online 2017: 11.

Das UN (2015). Cytokines, angiogenic, and antiangiogenic factors and bioactive lipids in preeclampsia. Nutrition 31: 1083-1095. http://dx.doi.org/10.1016/j.nut.2015.03.013

Djukic M, Gibson CS, Maclennan AH, Goldwater PN, et al. (2009). Genetic susceptibility to viral exposure may increase the risk of cerebral palsy. Aust. N. Z. J. Obstet. Gynaecol. 49: 247-253. http://dx.doi.org/10.1111/j.1479$\underline{828 X .2009 .00999 . X}$

Dekker GA and Sibai BM (1998). Etiology and pathogenesis of preeclampsia: current concepts. Am. J. Obstet. Gynecol. 179: 1359-1375. http://dx.doi.org/10.1016/S0002-9378(98)70160-7

Fraser R, Walker JJ, Ekbote UV, Martin KL, et al. (2008). Interleukin-4 -590 (C>T), toll-like receptor-2 +2258 (G>A) and matrix metalloproteinase-9 -1562 (C>T) polymorphisms in pre-eclampsia. BJOG 115: 1052-1056, discussion 1056. http://dx.doi.org/10.1111/j.1471-0528.2008.01771.x

Gao H, Liu C, Lin P, Xu L, et al. (2016). Effects of GSTP1 and GPX1 Polymorphisms on the Risk of Preeclampsia in Chinese Han Women. Cell. Physiol. Biochem. 39: 2025-2032. http://dx.doi.org/10.1159/000447898

Gharesi-Fard B, Mobasher-Nejad F and Nasri F (2016). The Expression of T-Helper Associated Transcription Factors and Cytokine Genes in Pre-Eclampsia. Iran. J. Immunol. 13: 296-308.

Gratacs E, Filella X, Palacio M, Cararach V, et al. (1998). Interleukin-4, interleukin-10, and granulocyte-macrophage colony stimulating factor in second-trimester serum from women with preeclampsia. Obstet. Gynecol. 92: 849e53.

Hod T, Cerdeira AS and Karumanchi SA (2015). Molecular mechanisms of preeclampsia. Cold Spring Harb. Perspect. Med. 5: a023473. http://dx.doi.org/10.1101/cshperspect.a023473

Kang L, Chen $\mathrm{CH}$, Yu CH, Chang CH, et al. (2014). An association study of interleukin-4 gene and preeclampsia in Taiwan. Taiwan. J. Obstet. Gynecol. 53: 215-219. http://dx.doi.org/10.1016/j.tjog.2014.04.017

Liu QY, Gao FY, Liu XR, Li J, et al. (2015). Investigations into the association between polymorphisms in the interleukin-10 gene and risk of early-onset preeclampsia. Genet. Mol. Res. 14: 19323-19328. http://dx.doi.org/10.4238/2015. December.29.42

Lwaleed BA, Cooper AJ and Kazmi RS (2011). Preface: Hemostatic factors in the etiology, early detection, prevention, and management of pre-eclampsia. Semin. Thromb. Hemost. 37: 95-96. http://dx.doi.org/10.1055/s-0030-1270333

Mansouri R, Akbari F, Vodjgani M, Mahboudi F, et al. (2007). Serum cytokines profiles in Iranian patients with preeclampsia. Iran. J. Immunol. 4: 179-185.

Mol BW, Roberts CT, Thangaratinam S, Magee LA, et al. (2016). Pre-eclampsia. Lancet 387: 999-1011. http://dx.doi. org/10.1016/S0140-6736(15)00070-7

Genetics and Molecular Research 16 (2): gmr16029218 
Paul WE (2015). History of interleukin-4. Cytokine 75: 3-7. http://dx.doi.org/10.1016/j.cyto.2015.01.038

Redpath SA, Heieis G and Perona-Wright G (2015). Spatial regulation of IL-4 signalling in vivo. Cytokine 75: 51-56. http://dx.doi.org/10.1016/j.cyto.2015.02.026

Ren X, Guo M, Liu C, Huang T, et al. (2016). A Case-Control Study Indicates that no Association Exists Between Polymorphisms of IL-33 and IL-1RL1 and Preeclampsia. Cell. Physiol. Biochem. 38: 1406-1414. http://dx.doi. org/10.1159/000443083

Sibai B, Dekker G and Kupferminc M (2005). Pre-eclampsia. Lancet 365: 785-799. http://dx.doi.org/10.1016/S01406736(05)71003-5

Smith AM, Bernstein DI, LeMasters GK, Huey NL, et al. (2008). Environmental tobacco smoke and interleukin 4 polymorphism (C-589T) gene: environment interaction increases risk of wheezing in African-American infants. $J$. Pediatr. 152:709-715, 715 .

Sun C, Zhang Q, Hu B and Zhang K (2016a). Investigation of the association between matrix metalloproteinase-9 genetic polymorphisms and development of pre-eclampsia in Chinese pregnant women. Genet. Mol. Res. 15. http://dx.doi. org/10.4238/gmr. 15038355

Sun L, Mao D, Cai Y, Tan W, et al. (2016b). Association between higher expression of interleukin-8 (IL-8) and haplotype $-353 \mathrm{~A} /-251 \mathrm{~A} /+678 \mathrm{~T}$ of IL-8 gene with preeclampsia: A case-control study. Medicine (Baltimore) 95: e5537. http:// dx.doi.org/10.1097/MD.0000000000005537

Tavakkol Afshari Z, Rahimi HR, Ehteshamfar SM, Ganjali R, et al. (2016). Tumor Necrosis Factor-a and Interleukin-1-b Polymorphisms in Pre-Eclampsia. Iran. J. Immunol. 13: 309-316.

Vargas-Rojas MI, Solleiro-Villavicencio H and Soto-Vega E (2016). Th1, Th2, Th17 and Treg levels in umbilical cord blood in preeclampsia. J. Matern. Fetal Neonatal Med. 29: 1642-1645. http://dx.doi.org/10.3109/14767058.2015. $\underline{1057811}$

Wang X, Guo M, Li S, Gong J, et al. (2016). The Role of the IL-12 polymorphism rs3212227 in preeclampsia in Chinese Han Women. Clin. Exp. Hypertens. 38: 388-392. http://dx.doi.org/10.3109/10641963.2015.1131289

Yang HJ (2013). Association between the interleukin-4 gene C-589T and C+33T polymorphisms and asthma risk: a metaanalysis. Arch. Med. Res. 44: 127-135. http://dx.doi.org/10.1016/j.arcmed.2013.01.009

Yoneyama Y, Sawa R, Suzuki S, Miura A, et al. (2002). Relation between adenosine deaminase activities and cytokineproducing T cells in women with preeclampsia. Clin. Biochem. 35: 303e6.

Zhenzhen L, Xianghua L, Qingwei W, Zhan G, et al. (2013). Three common polymorphisms in the IL-4 gene and cancer risk: a meta-analysis involving 5,392 cases and 6,930 controls. Tumour Biol. 34: 2215-2224. http://dx.doi. org/10.1007/s13277-013-0761-8

Genetics and Molecular Research 16 (2): gmr16029218 